\begin{tabular}{c} 
Volume and Issues Obtainable at Center for Sustainability Research and Consultancy \\
Journal of Business and Social Review in Emerging Economies \\
ISSN: 2519-089X \& ISSN (E): 2519-0326 \\
Volume 7: Issue 4 December 2021 \\
CSRᄃ \\
Journal homepage: www.publishing.globalcsrc.org/jbsee \\
\hline
\end{tabular}

\title{
Nexus among the Hofstede Cultural Dimensions and Consumer Brand Loyalty: Empirical Evidence from Pakistan
}

Iqra Hafeez, COMSATS University Islamabad, Sahiwal Campus, Pakistan Qamaruddin Maitlo, Department of Business Administration, Institute of Business Administration (IBA) Sukkur, Pakistan

Ishfaque Ahmed Lashari, School of Management, Wuhan University of Technology, Wuhan, China

*Khaliq Ur Rehman, Office of Research Innovation and Commercialization, University of Management \& Technology, Lahore, Pakistan

*Corresponding author's email: khaliqcheema@gmail.com

ARTICLE DETAILS
History
Revised format: Nov 2021
Available Online: Dec 2021

\section{Keywords}

Hofstede's Cultural

Dimensions, Consumer,

Brand Loyalty, Pakistan

\section{JEL Classification} $M 1, M 2$

\begin{abstract}
Purpose: The current research aims to investigate the nexus among Hofstede's national cultural dimensions and consumer brand loyalty in Southern Punjab, Pakistan. These cultural dimensions represent the independent fondness of one state of affairs over another that distinguishes the country's culture (rather than individuals) from each other.

Design/Methodology/Approach: Current research adopts a survey research method for data collection following the quantitative research strategy. Primary data through a selfadministrated questionnaire was collected from individuals in southern Punjab, Pakistan's major cities. Current research has targeted 1110 individuals for data collection, out of which 900 people responded positively to our instruments. Descriptive statistics, Spearman correlation, and multiple regressions techniques were used to analyze the impact of Hofstede's cultural dimensions on brand loyalty.

Findings: The current research findings are fascinating as spearman's correlation shows that Cultural dimensions have a positive relationship but are negatively associated with consumer brand loyalty. Multiple regression analysis results also show that cultural dimensions do not significantly impact consumer brand loyalty.

Implications/Originality/Value: In the Pakistani cultural context, brand loyalty does not take much influence from the cultural values, but there could be some other factors that may affect brand loyalty. Further researchers can explore the exciting reasons for the current research results. Future studies can also explore the other factors which may influence brand loyalty, especially in the culture of southern Punjab, Pakistan.
\end{abstract}

(C) 2021 The authors, under a Creative Commons AttributionNonCommercial 4.0 
Recommended citation: Hafeez, I., Maitlo, Q., Lashari, I. A. and Rehman, K. (2021). Nexus among the Hofstede Cultural Dimensions and Consumer Brand Loyalty: Empirical Evidence from Pakistan. Journal of Business and Social Review in Emerging Economies, 7 (4), 985-996.

\section{Introduction}

Brand loyalty has remained a topic of interest for both practitioners and academicians. Relationship marketing has its roots in brand loyalty (Chinomona, 2016). Several factors affect brand loyalty, such as brand benefits, after-sale services, added values, brand trust, genetic influence, price consciousness of consumers, and cultural values (Steenkamp, 2019). Producers and marketers usually analyze the market and sales to get the maximum share in the market. Situation analysis consists of 3Cs Company, Customers, and Competitors, which further extended to 5Cs with the addition of Climate and Collaborators (Todorov \& Akbar, 2018). Customer is the main motive of marketers and, without him, nothing can be produced or sold. An individual who purchases goods and services for use according to his taste, interest, need, income level, culture, awareness, and availability in the market is a consumer (Moliner-Velázquez, Fuentes-Blasco, \& Gil-Saura, 2019). Consumer buying behavior is a process of decisions and actions that a consumer involves during purchasing and using products and services (Gaur, Amini, Banerjee, \& Gupta, 2015; Sudha \& Sheena, 2017).

Consumers buy any product after crossing six stages of decisions making. First of which is problem recognition (awareness of need). Sometimes consumer is aware of their need and sometimes unaware. To stimulate the unaware needs of the consumer, marketers use advertisements to provide information and create demand. The second stage of consumer decision is information searching about the problem's solution that can be internal or external. After purchasing the product, a consumer can be satisfied or dissatisfied (Aguirre-Rodriguez, Bosnjak, \& Sirgy, 2012; Solomon, White, Dahl, Zaichkowsky, \& Polegato, 2017). If a consumer is satisfied, it will have a good image of the company, which will lead to brand loyalty. Brand loyalty means to re-buy your favorite products or services consistently in a future life, and brand loyalty is influenced by the situation, price advantages, and advertisement or references groups (IsHak et al., 2013).

In their study, Syed, Rehman, and Kitchlew (2018) described that brand loyalty is the competitor advantage of an organization over the other companies. Every company tries to create brand loyalty to reduce its market expenses and build a long-term relationship with the customers (Kapferer, 2008). There are six ways to create brand loyalty: competitor advantage, brand affiliation, credibility, accessibility, Connection ability, and repurchasing (Kotler \& Pfoertsch, 2006). Consumers try to purchase their favorite brand even at a high price, whether competitive brands are available with the same attribute in the market at a low price (Viswanathan, Torelli, Xia, \& Gau, 2009). For example, in the USA, people are loyal to Apple products, while in Finland, people are loyal customers of Nokia Phones, but the question arises why they are so. The answer is they are easy to use. Undoubtedly, a loyal customer is ready to purchase their favorite brand at a high price and, after purchase, promote their brand without getting any favor (Keller, Parameswaran, \& Jacob, 2011). Therefore, the brand's loyal customers are less influenced by advertisements or environmental factors (Iglesias, Singh, \& Batista-Foguet, 2011). Companies try their best to create brand loyalty in long-term relationships. Therefore, to understand Brand loyalty, you must understand attitudinal loyalty, behavior intent, behavioral loyalty, brand building loyalty, and trust loyalty. Attitudinal Loyalty has three main cognitive, affective, and behavioral intent dimensions. Its development is based on a brand image that can develop through media. Loyalty means consumer satisfaction, but satisfaction does not lead to loyalty. It can play a role in building loyalty, but saying this that customer satisfaction leads to loyalty, is not suitable. 
No doubt, it is pretty easy to convert a satisfied customer into a more loyal customer than an unsatisfied customer. Therefore, we can say that if the consumer's attitude is positive towards a brand, they will be more loyal so, by making a favorable attitude towards the brand, you can shift switching buyers to loyal buyers (Sheu, 2016). Behavioral Intent is an intermediary state between attitude and behavior. It appears in different forms, either to buy a product for the first time or repurchase commitment. Behavioral Loyalty focuses on the repeated buying behavior of the consumer. The consumer can be loyal to the brand or with the store from where he purchased. Behavior loyalty is a complex term and cannot be measured in the true sense.

Brand building activities build a brand image and can be divided into two major areas: brand image building and frequency programs (Kaushik, 2016). Promotion tools and advertisements will help develop a brand image. Consumer relationship also builds the brand image like the "Volkswagen Owners Association" and the "Mickey Mouse Club." Trust builds Loyalty. Therefore, perceptions, beliefs, ideas, and attitudes that family, society, or other institutions are the values, which refers to culture. Every country has its cultural dimensions that affect consumers' buying behavior. Therefore, marketers and producers always remained interested in examining the factors that affect consumer buying behavior. To know about the culture dimensions in 1983, Hofstede's conducted a study in 53 countries and identified five dimensions of culture. Therefore, the focus of the study is to measure the impact of cultural dimension on consumer buying behavior by replicating the same model of Hofstede's cultural dimension (Power Distance, Uncertainty Avoidance, Individualism-Collectivism, Masculinity-Femininity, and Confucian Dynamism). The current research study considers all dimensions except confusion dynamism.

\section{Literature Review}

Brand Loyalty is one of the essential factors in research and the commercial markets around the globe because organizations are heavily investing in loyalty programs (Reinartz \& Kumar, 2002). Still, most of the time, these programs generate temporal loyalty, where customers seem loyal while organizations cannot sustain those customers in the longer run (Jones, 1995). Consumers' loyalty can only be achieved by delivering superior customer experience and value (Reichheld \& Schefter, 2000; Shafiq, Shafique, Din, \& Cheema, 2013). One of the essential objectives for a company is to gain loyalty as it is much easier to attain existing customers than generate new customers as it requires less effort and resources than generating new customers (Naveed, Akhtar, \& Cheema, 2012). Loyalty counts for consumers' repeatedly purchasing the same product in a certain period, depending on the consumer's experience with the product. Loyalty refers to the consumer's behavioral factors, whether the consumer will purchase the specific product in the future or switch to alternates (Lin, Wu and Wang 2000). There are several factors determining brand loyalty. These factors can be product characteristics, Consumer characteristics, and market characteristics. Product characteristics includes quality, aesthetics, product line, brand popularity, packaging, new product trial, free gifts and vouchers etc. consumer characteristics involves perceived quality, repeated purchase, brand commitment, and consumer demographics(age and income level of consumers). Market characteristics include store location, advertisement, marketing strategy, market and store environment etc (East, Harris, Willson, \& Hammond, 1995; Lin, Wang, \& Wu, 2000; Rundle-Thiele \& Bennett, 2001). A significant work is already available on brand loyalty, different dimensions of brand loyalty as well as determinants and consequences of brand loyalty. However, brand loyalty has not been explored terms of national culture and its dimensions, especially in developing countries like Pakistan. The current study attempts to find how cultural dimensions given by Hofstede can influence consumer brand loyalty.

Khuhro, Bhutto, and Sarki (2015) examined the impact of university students' culture and lifestyle on brand meaning. They found a positive relationship between cultural values and 
lifestyles of university students. While (Lupyan \& Thompson-Schill, 2012) examined the impact of antecedents (perceived quality, perceived value, and trust) on consumer brand loyalty, they investigated the moderate effect of cultural values on consumer brand loyalty. The results showed that perceived value does not influence consumer brand loyalty while Hofstede's cultural dimensions significantly impact brand loyalty. Consumers with a high degree of collectivism are more loyal than individualists by replicating Hofstede's cultural dimensions. Five cultural dimensions, i.e., power distance, uncertainty avoidance, masculinity-femininity, individualismcollectivism, and Confucian work dynamics, take one eastern country, Taiwan, and one western country, the United States, to restudy their cultures by extending Hofstede's work investigating occupational culture in the higher education setting. The results showed a continuous change in the culture due to political, social, and economic factors. So the culture cannot be static; instead, it is dynamic $(\mathrm{Wu}, 2006)$.

Podrug, Filipović, and Stančić (2014) used Hofstede's national cultural dimensions in Central European countries (Croatia, Bosnia \& Herzegovina, and Slovenia). The findings showed that these countries have some similarities and differences according to value orientation in their countries. They examined a minor degree of power distance in these three countries, indicating that people want to live independently. Croatia has a lower degree of uncertainty avoidance, while Slovenia, Bosnia, and Herzegovina have a high degree of uncertainty avoidance that confirms the (Hofstede, 2001) research. Results on Individualism collectivism in this research also confirm the Hofstede assumption that there is a global shift from collectivism towards individualism. Croatia and Slovenia have masculinity dominancy that showed their people have a high degree of assertiveness, competitiveness, success, accomplishments, less cooperation, balanced life, care for others, etc.

In contrast, Bosnia and Herzegovina have a low degree of masculinity compared to the sample taken. Traditions, customs, rituals, and religions that confirm Hofstede's findings characterize these societies. Croatia, Bosnia, and Herzegovina have short-term orientation, while Slovenia has a slightly long-term orientation (Podrug et al., 2014). Sun, Lin, and Chou (2005) conducted an exploratory study in Australia. In this research, the main objective was to measure the effects of culture over marketing mix and consumer buying behavior because the previous studies did not cover these aspects. They only examined the effects of culture over brand loyalty. In this research, Hofstede's culture dimensions (Power Distance, Uncertainty Avoidance, IndividualismCollectivism, and Masculinity-Femininity) were considered. It was an empirical study to examine the effects of cultural dimensions on consumer-reported "proneness" to brand loyalty. The results showed that cultural values could affect brand loyalty and play a role in consumer decisionmaking.

Moreover, the result of the study will contribute to the exciting work. It is well-defined from the above research that culture is not a static thing; instead, it is a dynamic in its nature. Therefore, in this study, Hofstede's cultural values were used to measure their impact on consumer brand loyalty.

\section{Theoretical Framework}

Culture influences consumers' perceptions and reactions (Allman, Hewett, \& Kaur, 2019; Fan, Shen, Wu, Mattila, \& Bilgihan, 2018) which eventually affects their purchase decisions. Culture has remained an exciting topic, and it has been widely researched in social and behavioral sciences literature (Geert Hofstede, 1980; Inkeles \& Levinson, 1969; Miller, 2020; Triandis, 1996; Trompenaars, 1994). Culture is defined as "the collective programming of the mind, which distinguishes the members of one group or category of people from another" (Hofstede, 1997, p. 5). Hofstede (1980-1994) conducted a study over fifty-three countries and gave basic dimensions of differences among national cultures, which distinguishes one culture from others. Later on, 
some researchers criticized Hofstede's research; many critics opposed Hofstede's generalization of the study among different cultures (Yeh, 1988). On the other hand, Marchers adopted crosscultural research on attitudes and behaviors (Fam \& Merrilees, 1998; Liu, Sudharshan, \& Hamer, 2000) and cultural differences (Lim, 2016; Moran, Harris, \& Moran, 2007). Hofstede (1991) proposed that these cultural dimensions can differentiate national cultures. They can also use at the individual level within cultures. A wide range of studies is available in the literature that uses Hofstede's cultural dimensions at the individual level (Aycan, 2005; Suls, Martin, \& Wheeler, 2002). They conducted their study based on Hofstede's dimensions to determine brand loyalty at the individual level within cultural differences.

\section{Hypothesis Development}

The current research study has taken Hofstede's cultural dimensions (Individualism-collectivism, Uncertainty Avoidance, Power Distance, and Masculinity-femininity) as independent variables, whereas consumer brand loyalty was taken as a dependent variable. After reviewing the literature, four hypotheses were formulated based on the variables to achieve the study's objectives.

The first dimension given by Hofstede is Individualism. Individualism is an ethical psychological concept that focuses on human beings' perceptions about their life. Individualism refers to individuals' attitudes towards the concept of self (Dawar, Parker, \& Price, 1996). It defines that individualistic people think and judge independently by giving full authority to their thinking. Individualism elaborates the sovereignty of one's life, thinking, decision, liking and disliking, etc. They only think about their lives, not others, in their daily routine. Collectivism is the opposite of individualism, where people prioritize collective goals (Singelis, Triandis, Bhawuk, \& Gelfand, 1995). In collectivism, people think more about norms and social rights (Matsumoto, 2000). People who have a high degree of individualism are self-centered, and they take less influence on an advertisement, social norms, or advocacy. They will purchase those products to whom they like or are more suitable. According to Hofstede's cultural dimensions index, Pakistan has 14 for individualism and 86 for collectivism.

The second dimension of (G. Hofstede, 1980) is Uncertainty Avoidance. People remain satisfied, feel comfortable in their existing structured situation, and feel uncomfortable in the unstructured, new, unknown or unusual atmosphere and situation. Consumers who have a high degree of uncertainty avoidance remain more loyal to their existing brand than consumer who has a low degree of uncertainty avoidance. According to Hofstede's survey, the uncertainty avoidance in Pakistan is 70. The third dimension is masculinity. Masculinity preference assertiveness, accomplishment, and material success, while femininity refers to relationships, modesty, and caring for others. People who are high in masculinity are more independent and sovereign in their decisions; they are likely to get less influence of external factors and remain loyal to their existing brand. The masculinity score from Hofstede's survey was 50 in Pakistan.

The fourth dimension is Power Distance. Power distance means the extent to which the members of the social exercise and like to distribute the power unequally among individuals. Consumers who have a high degree of power distance accept more inequality in society than consumers who have a lower degree. In a high degree of power distance, people will buy the product by the influence of their reference groups: peers, superiors, friends, and family, while in a low degree of power distance, people will buy whatever they like without considering others. Therefore, the consumers who have a high degree of power distance remain less loyal to their existing products and easily switch to the new brands by the influence of reference groups. At the same time, consumers who have a low degree of power distance remain more loyal to their existing brands. In Pakistan, the power distance score is 55. 
H1: The consumer who has a high degree of individualism will be more loyal to the brand than a low degree of individualism.

H2: Consumers with a high degree of uncertainty avoidance have a greater proneness to brand loyalty than those who score low in uncertainty avoidance.

H3: Consumers with a high degree of masculinity are more loyal to their brand than consumers who have a low degree of masculinity.

H4: Individuals who score high in power distance will be less prone to brand loyalty than those who score low.

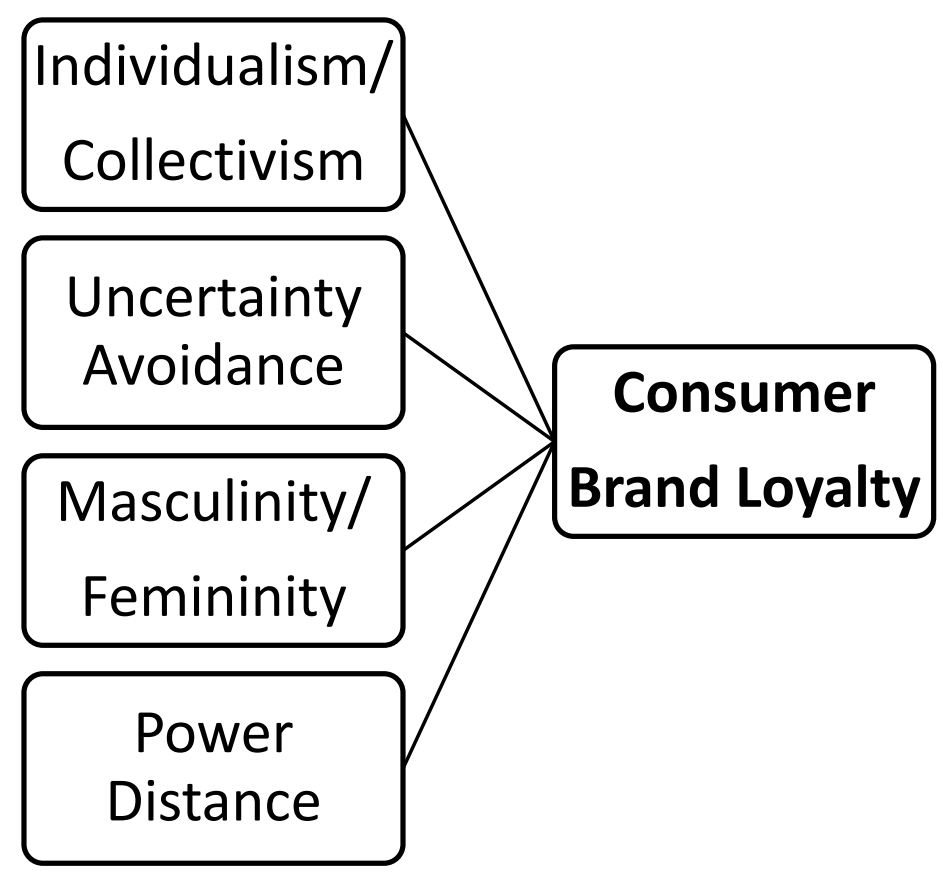

\section{Research Methodology}

Following the quantitative research strategy, current research adopted the questionnaire survey method to collect primary empirical evidence to validate the research objectives. In total1100, individuals were targeted by following the convenience and random sampling technique from significant cities of southern Punjab, Pakistan. Out of these 1100, only 900 respondents positively took part in the research. To measure Hofstede's cultural dimensions questionnaire has been adapted from (Hofstede \& Bond, 1984), and for the consumer brand loyalty, the instrument was adapted from (Ghafoor, Iqbal, Tariq, \& Murtaza, 2012). The instruments are valid and reliable as they were already used in different studies in different contexts. The questionnaire is divided into two sections. The first section contains the questions related to the respondents' personal information, i.e., age, gender, qualification, family structure, social class, and nature of the job. The second part of the questionnaire consists of questions regarding independent variables (Hofstede's cultural dimensions, i.e., Individualism-Collectivism, Uncertainty Avoidance, Power Distance and Masculinity-Femininity) and the dependent variable (consumer brand loyalty) measured in an ordinal scale. Measuring the impact of Hofstede's cultural dimensions on Consumer Brand loyalty, the following regression was proposed and empirically tested $\mathrm{c}_{\mathrm{t}}=\beta_{0}+$ $\beta_{1}$ Individualism-Collectivism $c, t+\beta_{2}$ Uncertainty Avoidance $+\beta_{3}$ Power Distance $+\beta_{4}$ Masculinity-Femininity $+\varepsilon \mathrm{c}, \mathrm{t}$ Where: $\beta_{0}-$ constant, $\varepsilon-$ Model error, $\mathrm{c}-$ Consumer, $\mathrm{t}-$ Purchasing at a particular time.

\section{Results and Discussion}

Descriptive statistics analysis is used to measure personal factors; the results of descriptive statistics are described in table 1 below.

Table 1 Demographic Information of the Respondents

Range Minimum $\quad$ Maximum $\quad$ Mean $\quad$ Std. Deviation




\begin{tabular}{|c|c|c|c|c|c|}
\hline Age Of Participant & 2.00 & 2.00 & 4.00 & 2.3905 & .52797 \\
\hline Gender & 3.00 & 1.00 & 4.00 & 1.5905 & .78072 \\
\hline Family Income & 3.00 & 1.00 & 4.00 & 3.2952 & 1.05542 \\
\hline Type Of Family & 3.00 & 1.00 & 4.00 & 1.7714 & .50492 \\
\hline Social Class & 3.00 & 1.00 & 4.00 & 2.2095 & .58335 \\
\hline $\begin{array}{l}\text { Education } \\
\text { Participant }\end{array}$ & 5.00 & 1.00 & 6.00 & 3.6095 & 1.11368 \\
\hline Location & 4.000 & 1.00 & 5.00 & 1.4381 & .783530 \\
\hline Nationality & .00 & 1.00 & 1.00 & 1.0000 & .00000 \\
\hline Occupation & 5.00 & 1.00 & 6.00 & 2.3429 & .66258 \\
\hline Nature Of Job & 4.00 & 3.00 & 7.00 & 5.3810 & .75168 \\
\hline
\end{tabular}

Descriptive statistics results have shown that a maximum number of people belong to the age group of 20-30, whereas a minimum number of participants fall in 40-50 years. Male respondents were in more significant numbers as compared to female respondents. Maximum participants have more than 50,000 rupees monthly income, whereas minimum respondents earn below 25,000 rupees. Maximum respondents live in the joint family system while the minimum is living in a nuclear family. There are three main categories of social classes in Pakistan. i.e., Upper class, upper Middle class, and Working-class. In this study, maximum participants are from the middle class, and the minimum is from the upper class. The maximum respondents of the study have a master's level of education, and the minimum respondents have intermediate-level education. The sample was taken from the cities of southern Punjab, Pakistan. The nature of the job of maximum participants was teaching whereas the minimum was trained officers,

Table 2 Reliability Analysis

\begin{tabular}{ll}
\hline Items & Cronbach's Alpha \\
\hline Independent & .705 \\
\hline Dependndet & .758 \\
\hline
\end{tabular}

The reliability of independent and dependent variables was analyzed by comparing the calculated value of Cronbach's alpha through the scale reliability technique with the standardized value of Cronbach's alpha. Cronbach's alpha scores are more than 0.70 for the independent variable and dependant variable that suggested reliability in the item of the variables.

Table 3 Spearman Correlation Analysis

\begin{tabular}{llllll}
\hline Spearman's rho & & Indv. & UA & M \& F & P D \\
\hline Uncertainty Avoidance & Correlation Coefficient & $.388^{* *}$ & & & \\
Masculinity And Faminity & Correlation Coefficient & $.350^{* *}$ & $.403^{* *}$ & & \\
Power Distance & Correlation Coefficient & .150 & $.236^{*}$ & .062 & \\
Consumer Brand Loyalty & Correlation Coefficient & .119 & .151 & .059 & .023 \\
\hline & $* *$ Correlation is significant at the 0.01 level (2-tailed). \\
& $*$. Correlation is significant at the 0.05 level (2-tailed).
\end{tabular}

Spearman's correlation technique has been used to test the correlation between the dependent and independent variables. Results of spearman's correlation have are given in table 1.3. Results describe that Individualism-Collectivism Has Positive and Significant Correlation with Uncertainty Avoidance (0.388) and masculinity and femininity $(0.350)$ but no correlation with power distance $(0.150)$ and consumer brand loyalty (0.119). Uncertainty avoidance is positive and significantly correlated with individualism (0.388) and masculinity and Femininity (0.403) but weak correlation with power distance $(0.236)$ whereas no correlation with consumer brand loyalty (0.151). Masculinity and femininity have a positive and significant correlation with individualism-collectivism (0.350) and uncertainty avoidance (0.403) but do not correlate with power distance (0.062) and consumer brand loyalty (0.059). Power distance has a positive and significant correlation with uncertainty avoidance. There is no correlation among individualism (0.150), masculinity and femininity (0.062), and consumer brand loyalty (0.023). Consumer 
brand loyalty has no correlation among Hofstede's cultural dimensions, i.e., individualism, uncertainty avoidance, masculinity and femininity, power distance. It means that if independent variable increase in value, the dependent variable will not increase. Similarly, when independent variable decrease, the dependent variable will not decrease because they do not correlate. The significance (2-tailed) values were not less than 0.05 , which described that $\mathrm{H} 1, \mathrm{H} 2, \mathrm{H} 3$, and $\mathrm{H}_{4}$ are not in the acceptable region.

Table 4 Model Summary of Multiple Regressions Analysis

\begin{tabular}{llllllll}
\hline Model & Variables Entered & $\mathbf{R}$ & $\begin{array}{l}\mathbf{R} \\
\text { Square }\end{array}$ & $\begin{array}{l}\text { Adjusted } \\
\text { Square }\end{array}$ & $\begin{array}{l}\text { Std. Error of } \\
\text { the Estimate }\end{array}$ & $\begin{array}{l}\text { Durbin- } \\
\text { Watson }\end{array}$ \\
\hline $\mathbf{1}$ & Individualism & $.187^{\mathrm{a}}$ & .035 & .026 & .33191 & \\
$\mathbf{2}$ & $\begin{array}{l}\text { Uncertainty } \\
\text { Avoidance }\end{array}$ & $.196^{\mathrm{b}}$ & .038 & .019 & .33299 & \\
$\mathbf{3}$ & $\begin{array}{l}\text { Masculinity } \\
\text { Faminity }\end{array}$ & $.217^{\mathrm{c}}$ & .047 & .019 & .33307 & \\
$\mathbf{4}$ & \begin{tabular}{l} 
Power Distance \\
\hline
\end{tabular} & $.219^{\mathrm{d}}$ & .048 & .010 & .33463 & 1.942 \\
\hline
\end{tabular}

Multiple regression analysis is used to examine the relationship between dependant and independent variables; when there is more than one variable in the model, and adjusted R square value is used to balance the effect of independent variables. The value of adjusted $r$ square is 0.026 for individualism 0.019. for uncertainty avoidance, and same for masculinity and femininity and 0.10 for power distance which exhibits that change in the overall consumer brand loyalty is $7.4 \%$ due to Hofstede's culture dimension is not significant It also showed the degree of influence of independent variable over dependent variable is the week in this model. The Durbin-Watson test value is 1.942, within the acceptable range of 1.5-2.5, which describes no autocorrelation and multicollinearity among dependent and independent variables.

Table 5 ANOVA

\begin{tabular}{|c|c|c|c|c|c|c|}
\hline Model & & Sum of Squares & df & Mean Square & $\mathbf{F}$ & Sig. \\
\hline \multirow[t]{3}{*}{1} & Regression & .413 & 1 & .413 & 3.750 & $.056^{\mathrm{b}}$ \\
\hline & Residual & 11.347 & 103 & .110 & & \\
\hline & Total & 11.760 & 104 & & & \\
\hline \multirow[t]{3}{*}{2} & Regression & .450 & 2 & .225 & 2.029 & $.137^{\mathrm{c}}$ \\
\hline & Residual & 11.310 & 102 & .111 & & \\
\hline & Total & 11.760 & 104 & & & \\
\hline \multirow[t]{3}{*}{3} & Regression & .555 & 3 & .185 & 1.669 & $.178^{\mathrm{d}}$ \\
\hline & Residual & 11.204 & 101 & .111 & & \\
\hline & Total & 11.760 & 104 & & & \\
\hline \multirow[t]{3}{*}{4} & Regression & .562 & 4 & .140 & 1.255 & $.293^{\mathrm{e}}$ \\
\hline & Residual & 11.198 & 100 & .112 & & \\
\hline & Total & 11.760 & 104 & & & \\
\hline
\end{tabular}

A two-way ANOVA test was used to explore the nexus among Hofstede's cultural dimensions and consumer brand loyalty. Results revealed no significant impact of Hofstede's Cultural dimensions on consumer brand loyalty $(\mathrm{p}<0.05)$ for all four independent variables. In this case, the $\mathrm{F}$ ratio is low, and the significance value is above 0.05 . There are more than one independent variable and one dependent variable in current research, so a multiple regression model has been applied.

Table 6 Regression Coefficient

\begin{tabular}{|c|c|c|c|c|c|c|}
\hline \multicolumn{2}{|c|}{ Model } & \multicolumn{2}{|c|}{ Un-standardized Coefficients } & $\begin{array}{l}\text { Standardized } \\
\text { Coefficients } \\
\text { Beta }\end{array}$ & $\mathbf{T}$ & Sig. \\
\hline \multirow[t]{2}{*}{1} & (Constant) & 3.351 & .131 & & 25.555 & .000 \\
\hline & Individualism & .122 & .063 & .187 & 1.936 & .056 \\
\hline \multirow[t]{3}{*}{2} & (Constant) & 3.324 & .139 & & 23.857 & .000 \\
\hline & Individualism & .098 & .076 & .150 & 1.293 & .199 \\
\hline & $\begin{array}{l}\text { Uncertainty } \\
\text { Avoidance }\end{array}$ & .032 & .056 & .067 & .576 & .566 \\
\hline
\end{tabular}




\begin{tabular}{|c|c|c|c|c|c|c|}
\hline \multirow[t]{7}{*}{3} & (Constant) & 3.461 & .198 & & 17.478 & .000 \\
\hline & Individualism & .111 & .077 & .171 & 1.448 & .151 \\
\hline & Uncertainty & .048 & .059 & .100 & .826 & .411 \\
\hline & Avoidance & & & & & \\
\hline & Masculinity & -.071 & .072 & -.106 & -.975 & .332 \\
\hline & And & & & & & \\
\hline & Faminity & & & & & \\
\hline \multirow[t]{9}{*}{4} & (Constant) & 3.428 & .242 & & 14.152 & .000 \\
\hline & Individualism & .111 & .077 & .171 & 1.435 & .154 \\
\hline & Uncertainty & .045 & .061 & .093 & .740 & .461 \\
\hline & Avoidance & & & & & \\
\hline & Masculinity & -.069 & .073 & -.103 & -.940 & .350 \\
\hline & And & & & & & \\
\hline & Faminity & & & & & \\
\hline & POWER & .012 & .051 & .025 & .242 & .809 \\
\hline & DISTANCE & & & & & \\
\hline
\end{tabular}

a. Dependent Variable: Consumer Brand Loyalty

The regression coefficient table represents that $\mathrm{B}_{0}=$ constant value is 3.428 , which is too high, whereas $\beta_{1}=0.111, \beta_{2}=0.045, \beta_{3}=-0.069$, and $\beta_{4}=0.012$, which shows that Hofstede's cultural dimensions do not have a significant impact on consumer brand loyalty. After analyzing the results, it concluded that $\mathrm{H} 1, \mathrm{H} 2, \mathrm{H} 3$, and $\mathrm{H} 4$ fall in the rejection region.

\section{Conclusion}

Results of the study suggest that consumer brand loyalty is not influenced by cultural values (Lim, 2016) also found in their research that only H1(The consumer who has a high degree of individualism will be more loyal to brand compared to a low degree of individualism). And $\mathrm{H} 2$ (Consumers who have a high degree of uncertainty avoidance have a greater proneness to be brand loyal than those who score low in uncertainty avoidance) positively impact consumer brand loyalty. But H3(Consumers who have a high degree of masculinity are more loyal to their brand as compared to the consumer who has a low degree of masculinity) and H4(Individuals who score high in power distance will be less prone to brand loyalty than those who score low in power distance) rejected in their study. This research suggests that $\mathrm{H} 1$ and $\mathrm{H} 2$ are also rejected along with $\mathrm{H} 3$ and H4. Therefore, in Pakistan, cultural dimensions of Hofstede's Model have a low impact on consumer brand loyalty. Some research positively influences consumer brand loyalty due to different cultural traits and values because cultural index varies from one country to another. The study's findings will provide a guideline for the producers and marketers to understand that cultural dimensions negatively impact consumer brand loyalty. Brand loyalty is the ultimate task of any company so that they may reduce their per-unit cost and enhance their market share so; these findings help them to understand that there are some factors other than cultural values which have a positive and substantial impact on consumer brand loyalty other than cultural values in Pakistan. The results are accurate and helpful for stakeholders, but they also have limitations such as sample size, variables, survey tool, and a single research approach. For future researchers, there is an opportunity to find out the relationship of brand loyalty with other factors by adopting different research methods, approaches, tools, and variables to contribute to the existing body of knowledge.

\section{References}

Aguirre-Rodriguez, A., Bosnjak, M., \& Sirgy, M. J. (2012). Moderators of the self-congruity effect on consumer decision-making: A meta-analysis. Journal of Business Research, 65(8), 1179-1188.

Allman, H. F., Hewett, K., \& Kaur, M. (2019). Understanding Cultural Differences in Consumers' Reactions to Foreign-Market Brand Extensions: The Role of Thinking Styles. Journal of International Marketing, 27(2), 1-21. 
Aycan, Z. (2005). The interplay between cultural and institutional/structural contingencies in human resource management practices. The International Journal of Human Resource Management, 16(7), 1083-1119.

Chinomona, R. (2016). Brand communication, brand image and brand trust as antecedents of brand loyalty in Gauteng Province of South Africa. African Journal of Economic and Management Studies, 7(1), 124-139.

Dawar, N., Parker, P. M., \& Price, L. J. (1996). A cross-cultural study of interpersonal information exchange. Journal of international business studies, 27(3), 497-516.

East, R., Harris, P., Willson, G., \& Hammond, K. (1995). Correlates of first-brand loyalty. Journal of Marketing Management, 11(5), 487-497.

Fam, K. S., \& Merrilees, B. (1998). Cultural values and personal selling. International Marketing Review.

Fan, A., Shen, H., Wu, L., Mattila, A. S., \& Bilgihan, A. (2018). Whom do we trust? Cultural differences in consumer responses to online recommendations. International Journal of Contemporary Hospitality Management.

Gaur, J., Amini, M., Banerjee, P., \& Gupta, R. (2015). Drivers of consumer purchase intentions for remanufactured products: A study of Indian consumers relocated to the USA. Qualitative Market Research: An International Journal, 18(1), 30-47. doi:10.1108/QMR01-2014-0001

Ghafoor, M. M., Iqbal, H. K., Tariq, U., \& Murtaza, F. (2012). Impact of customer satisfaction and brand image on brand loyalty. Progress in Business Innovation \& Technology Management, 2(2), 69-77.

Hofstede, G. (1980). Culture and organizations. International Studies of Management \& Organization, 10(4), 15-41.

Hofstede, G. (1980). Values and Culture. Culture's Consequences : International Differences in Work-Related Values.

Hofstede, G. (2001). Culture's consequences: Comparing values, behaviors, institutions and organizations across nations: Sage publications.

Hofstede, G., \& Bond, M. H. (1984). Hofstede's culture dimensions: An independent validation using Rokeach's value survey. Journal of cross-cultural psychology, 15(4), 417-433.

Iglesias, O., Singh, J. J., \& Batista-Foguet, J. M. (2011). The role of brand experience and affective commitment in determining brand loyalty. Journal of Brand Management, 18(8), 570-582.

Inkeles, A., \& Levinson, D. J. (1969). National character: The study of modal personality and sociocultural systems. The handbook of social psychology, 4, 418-506.

IsHak, W. W., Elbau, I., Ismail, A., Delaloye, S., Ha, K., Bolotaulo, N. I., . . Wang, C. (2013). Quality of life in borderline personality disorder. Harvard review of psychiatry, 21(3), 138-150.

Jones, T. a. W. E. S. J. (1995). "Why Satisfied Customers Defect,". Harvard business review, 73(6), 88-99.

Kapferer, J.-N. (2008). The new strategic brand management: Creating and sustaining brand equity long term: Kogan Page Publishers.

Kaushik, K. (2016). Analyzing the effect of brand building activities on brand image using topic modeling techniques: student research abstract. Paper presented at the Proceedings of the 31st Annual ACM Symposium on Applied Computing.

Keller, K. L., Parameswaran, M., \& Jacob, I. (2011). Strategic brand management: Building, measuring, and managing brand equity: Pearson Education India.

Khuhro, R. A., Bhutto, N. A., \& Sarki, I. H. (2015). Failure of Brand Intoxication with the Mediating Effect of Ad Skepticism. Sukkur IBA Journal of Management and Business, 2(1), 85-101.

Kotler, P., \& Pfoertsch, W. (2006). B2B brand management: Springer Science \& Business Media. 
Lim, N. (2016). Cultural differences in emotion: differences in emotional arousal level between the East and the West. Integrative medicine research, 5(2), 105-109.

Lin, C., Wang, Z., \& Wu, W. (2000). A study of market structure: brand loyalty and brand switching behaviours for durable household appliances. International Journal of market research, 42(3), 1-16.

Liu, B. S.-C., Sudharshan, D., \& Hamer, L. O. (2000). After-service response in service quality assessment: a real-time updating model approach. Journal of Services Marketing, 14(2), 160-177.

Lupyan, G., \& Thompson-Schill, S. L. (2012). The evocative power of words: activation of concepts by verbal and nonverbal means. Journal of Experimental Psychology: General, 141(1), 170.

Matsumoto, D. (2000). Culture and psychology: People around the world, 2nd ed. Belmont, CA, US: Wadsworth/Thomson Learning.

Miller, V. (2020). Understanding digital culture: SAGE Publications Limited.

Moliner-Velázquez, B., Fuentes-Blasco, M., \& Gil-Saura, I. (2019). Effects of value and innovation on brand equity in retailing. Journal of Brand Management, 26(6), 658-674.

Moran, R. T., Harris, P. R., \& Moran, S. (2007). Managing cultural differences: Routledge.

Naveed, T., Akhtar, I., \& Cheema, K. U. R. (2012). The impact of innovation on customer satisfaction and brand loyalty: A study of the students of Faisalabad.

Podrug, N., Filipović, D., \& Stančić, I. (2014). Analysis of cultural differences between Croatia, Brazil, Germany and Serbia. Economic research-Ekonomska istraživanja, 27(1), 818-829.

Reichheld, F. F., \& Schefter, P. (2000). E-loyalty: your secret weapon on the web. Harvard business review, 78(4), 105-113.

Reinartz, W., \& Kumar, V. (2002). The mismanagement of customer loyalty. Harvard business review, 80(7), 86-94, 125.

Rundle-Thiele, S., \& Bennett, R. (2001). A brand for all seasons? A discussion of brand loyalty approaches and their applicability for different markets. Journal of Product \& Brand Management.

Shafiq, Y., Shafique, I., Din, M. S., \& Cheema, K. U. R. (2013). Impact of Service quality on customer satisfaction: a study of hotel industry of Faisalabad, Pakistan.

Sheu, J. B. (2016). Buyer behavior in quality-dominated multi-sourcing recyclable-material procurement of green supply chains. Production and Operations Management, 25(3), 477-497.

Singelis, T. M., Triandis, H. C., Bhawuk, D. P. S., \& Gelfand, M. J. (1995). Horizontal and Vertical Dimensions of Individualism and Collectivism: A Theoretical and Measurement Refinement. Cross-Cultural 240-275. doi:10.1177/106939719502900302

Solomon, M. R., White, K., Dahl, D. W., Zaichkowsky, J. L., \& Polegato, R. (2017). Consumer behavior: Buying, having, and being: Pearson Boston, MA.

Steenkamp, J.-B. E. (2019). Global versus local consumer culture: Theory, measurement, and future research directions. Journal of International Marketing, 27(1), 1-19.

Sudha, M., \& Sheena, K. (2017). Impact of influencers in consumer decision process: the fashion industry. SCMS Journal of Indian Management, 14(3), 14-30.

Suls, J., Martin, R., \& Wheeler, L. (2002). Social comparison: Why, with whom, and with what effect? Current directions in psychological science, 11(5), 159-163.

Sun, Y., Lin, C.-S., \& Chou, Y. (2005). Gene transfection and expression in a primary culture of mammary epithelial cells isolated from lactating sows. Cell biology international, 29(7), 576-582.

Todorov, K., \& Akbar, Y. H. (2018). Generic Strategiese-Pay Malaysia: The Next 10 YearsCase Study: Inchcape plc Part 7. In Strategic Management in Emerging Markets: Emerald Publishing Limited. 
Triandis, H. C. (1996). The psychological measurement of cultural syndromes. American psychologist, 51(4), 407.

Trompenaars, F. (1994). Riding the waves ofculture. Burr Ridge, IL: Irwin Professional.

Viswanathan, M., Torelli, C. J., Xia, L., \& Gau, R. (2009). Understanding the influence of literacy on consumer memory: The role of pictorial elements. Journal of Consumer Psychology, 19(3), 389-402.

Wu, M. (2006). Hofstede's cultural dimensions 30 years later: A study of Taiwan and the United States. Intercultural communication studies, 15(1), 33.

Yeh, R.-s. (1988). On Hofstede's treatment of Chinese and Japanese values. Asia Pacific Journal of Management, 6(1), 149-160. 